\title{
IDENTIFICATION OF HETEROGENEITIES IN THE UPPER PART OF GEOLOGICAL MEDIUM WITH GROUND PENETRATING RADAR VIY3-300
}

\section{ВИЯВАЕННЯ НЕОАНОРІАНОСТЕЙ У ВЕРХНІЙ ЧАСТИНІ ГЕОЛОГІЧНОГО СЕРЕАОВИЩА ЗА АОПОМОГОЮ IEOPAAAPA VIY3-300}

\author{
А.П. Чернов, Р.П. Голяка \\ Anatolii P. Chernov, Roman P. Goliaka
}

Institute of Geology, Taras Shevchenko National University of Kyiv, 90 Vasylkivska str., Kyiv 03022, Ukraine, (achernovp@gmail.com)

\begin{abstract}
ПреАставлено результати АосліАжень по виявленню різного роду неоАноріАностей в геологічному сереАовищі за Аопомогою георадара. Наведено опис методики виконання досліАжень за допомогою георадара та опис використаної апаратури. АосліАження проведено в Україні на експериментально-навчальному полігоні, гранітному кар'єрі та на місцях виходу на поверхню кристалічних поріА. За результатами досліАжень встановлено, що георадаром VIY3-300 (частота антенного блоку 300 MHz) можна виявити тріщини, металічні та пластикові труби, границю між пластами з різною структурою та різною діелектричною проникністю, визначити глибину їх залягання та в окремих випадках визначити геометричні параметри об'єктів пошуку. К^ючові слова: георадар, радарограма, інженерна геологія, граніт, приповерхнева геофізика.
\end{abstract}

This paper is devoted to investigations of heterogeneities in the geological medium with GPR. The main principles of GPR surveying settings for VIY3-300 (300 MHz antenna) GPR are mentioned in that paper. Results of investigations are represented by radarograms with matches of observed objects on four sites of investigations: 1. Experimental polygon. 2. Granite quarry. 3. Exposure of granite and their coverage by sedimentary rocks. 4. Evaluation of the depth to the borders between layers of soil and building materials. According to the results, it is possible to detect fissures, metal and plastic pipes, border between layers with different permittivity VIY3-300 (300 MHz antenna) GPR .

Keywords: ground penetrating radar, GPR, radargram, engineering geology, granite, near surface geophysics.

\section{INTRODUCTION}

During the last $20-25$ years ground penetrating radars (GPR) became widely used geophysical method for solving problems of near surface geophysics. There are two major groups of problems, which could be solved with GPR: 1. Geological structures mapping, geotechnical and hydrogeological problems - mapping of geological structures, evaluation of the depth to the ground water, evaluation of the ice thickness. 2. Identification and examination of artificial objects - pipelines, cables, buried industrial wastes, foundation of the buildings, identification of hidden fissures in the walls, heterogeneities in the construction of roads and railways, historical heritage etc (Chernov, Goliaka, 2015).

Therefore, authors have done investigations of artificial objects (experimental polygon with different objects, identification of border between foundation of the building and natural soil) and geological structures to test productivity of applied VIY3-300 GPR with $300 \mathrm{MHz}$ antenna for further investigations of such kind of objects.

\section{THEORETICAL BACKGROUND}

Ground penetrating radar is a device, which radiate electromagnetic waves and then record electro- magnetic signal, which is reflected from the boundaries between parts of the medium with different permittivity.

As usual GPR device contains transmitting and receiving antennas. The transmitter radiate electromagnetic wave and receiver record reflected electromagnetic signal. In some occasions, GPR has one antenna, which radiate and receive signal. According to different construction of antennas, there are several types of them: monopoles, dipoles, conical and bow-tie antennas (Daniels, 2004, Vladov, 2004). Depending on the frequency of antennas and architecture of the devices, relative position between transmitter and receiver can vary and according to Daniels (Daniels, 2004) there are four modes of GPR surveying: common offset; common depth point; common source and common receiver. The most widely used is considered to be common offset, when distance between receiver and transmitter is fixed (Daniels, 2004). While surveying in each point (with exact step) of the profile trace is recorded. As a result, GPR profile or radargram contains all traces, which were recorded along each direction of surveying. Resolution of survey and depth of investigations primarily depend on frequency of the signal and permittivity of 
the medium - as higher frequency as shorter length of the electromagnetic wave and so smaller objects could be identified, as higher permittivity as stronger attenuation of the signal and so shallower depth of the surveying.

After signal processing with special tools (gain, filters of high and low frequencies etc.), anomalies could be localized and interpreted according to the next rule: a set of reflections can form a straight line in case of flat or tilted border, and hyperbola anomaly, when signal reflects from local objects (small point-like heterogeneity), and in this occasion object is in the top of this hyperbola (Persico, 2014). Moreover, according to theoretical basics of the method (Daniels, 2004 Persico, 2014), when angle between branches of hyperbola-like anomaly is known, it is possible to get information about velocity of electromagnetic wave propagation and geometrical parameters of the object.

\section{DESCRIPTION OF THE DEVICE \\ AND APPLIED TECHNICS}

For investigations VIY3-300 GPR was applied. This equipment is manufactured by Ukrainian LLC "Transient Technologies". This device is designed to detect heterogeneities in the soil, building structures to the depth (thickness) of 8-12 m. This device may be applied to solve above mentioned problems. Odometer and/or GPS could be connected to the ground penetrating radar to know precise step in meters between measurement points. Device could be connected to the computer via Wi-Fi or with USB cable. VIY3-300 GPR is designed as a common offset modification with bow-tie antennas.

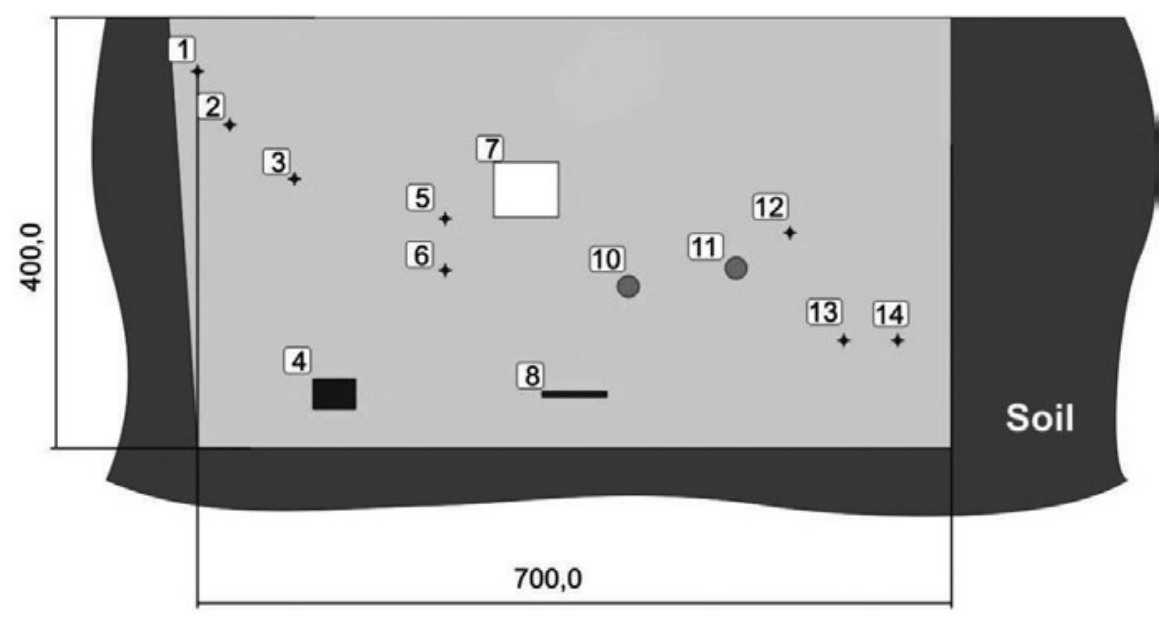

a

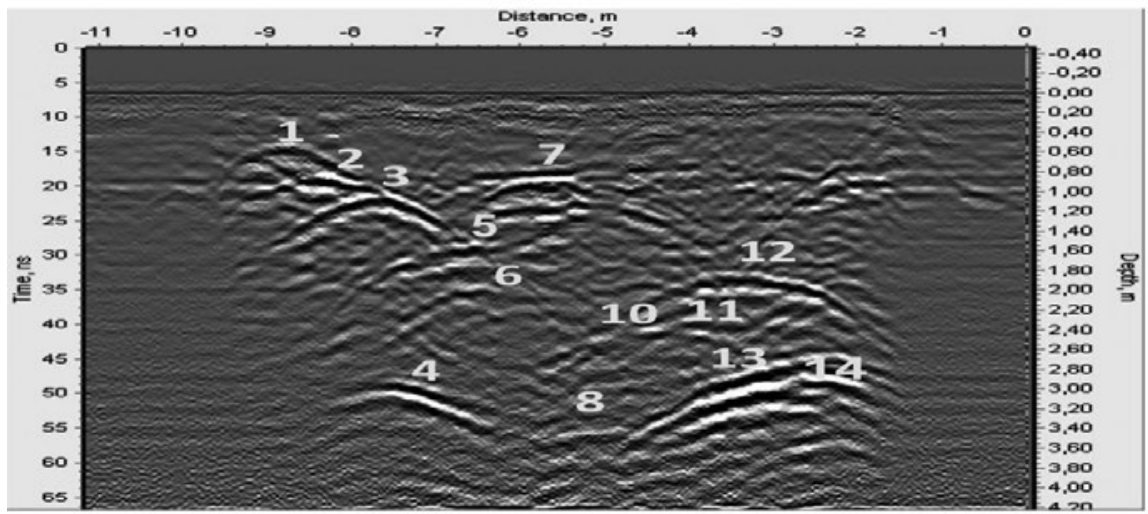

b

Fig. 1. Experimental polygon:

a - cross-section with location of the objects according to their position during construction of the polygon: 1,2 - steel pipes, diameter $5 \mathrm{~cm}$, length $1 \mathrm{~m} ; 3,13$ - steel pipes, diameter $5 \mathrm{~cm}$, length $2 \mathrm{~m}$ with wire inside; 4 - metal box $(0.5 \mathrm{~m} \times 0.8 \mathrm{~m} \times 0.4 \mathrm{~m}$, empty inside); 5, 6, 12, 14 - steel pipes, diameter $5 \mathrm{~cm}$, length $2 \mathrm{~m} ; 7$ - styrofoam $(1 \mathrm{~m} \times 0.5 \mathrm{~m} \times 0.5 \mathrm{~m}) ; 8$ - metal plane $(0.8 \times 0.8 \mathrm{~m}) ; 10$, 11 - plastic pipe diameter $20 \mathrm{~cm}$, length $220 \mathrm{~cm}$; b - radargram obtained on the polygon, numbers for anomalies correspond to the numbers on the picture with cross-section. 


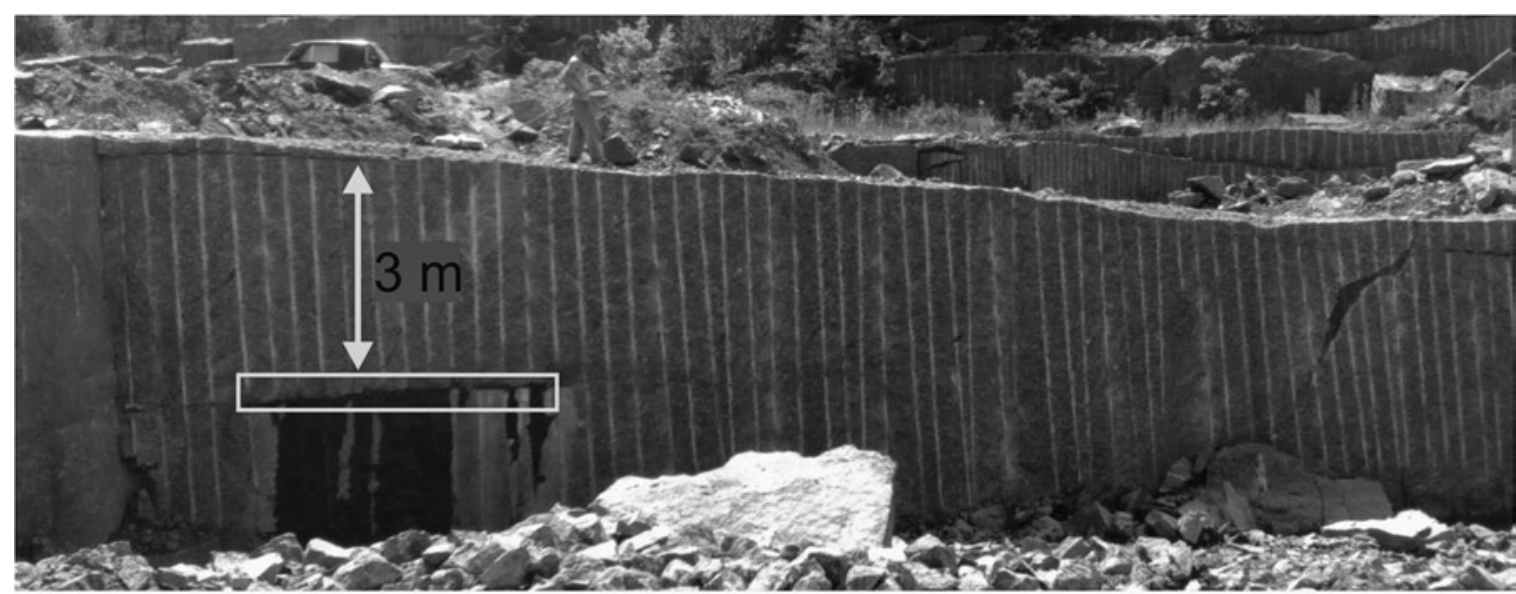

a

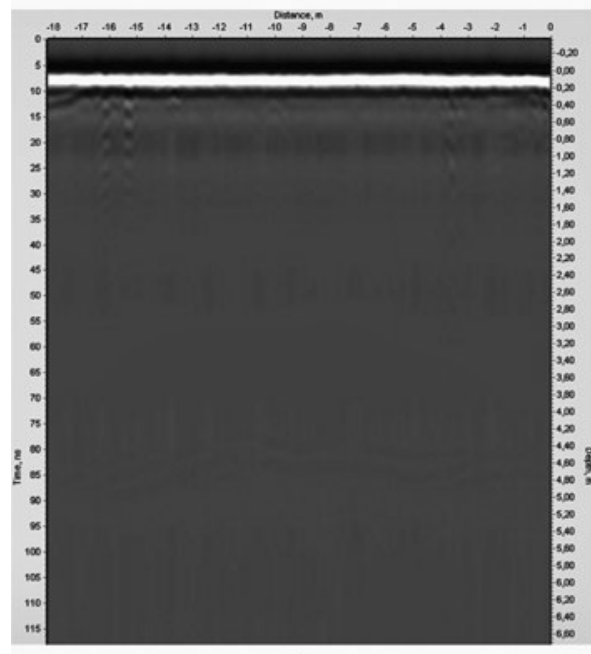

b

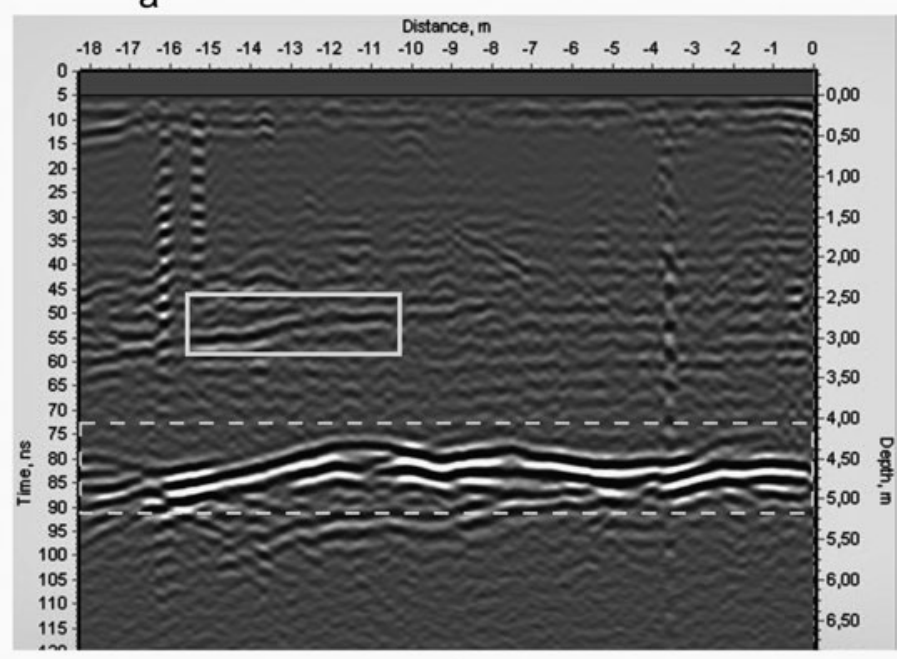

C

Fig. 2. Granite quarry: $a$ - picture from the quarry of cross-section of investigated area; $b$ - radargram before processing; c - radargram after processing. Anomalies are marked with rectangles: solid line for fissure with water and dashed line for fissure between granite blocks.

Main specifications of VIY3-300: antenna system frequency: $300 \mathrm{MHz}$; Analogue-to-Digital Converter range: 18 bits; Dynamic range: at least $135 \mathrm{~dB}$; measuring speed: up to 55 traces per second; Step of measurement: from $30 \mathrm{~mm}$ to 3200 mm; survey window: 66, 100, 133, 166 ns; the maximum number of samples per trace: 1000; Trace stacking number: up to 300; probing depth: to 12 meters (determined by the properties of rocks); spatial resolution: not worse than $0.3 \mathrm{~m}$; trigger mode: single, internal, external; File size up to 1 million traces; Interface: USB2.0 or Wi-Fi; Dimensions: 610 × 312 × 170 mm; Weight: $9 \mathrm{~kg}$; Operating temperature range: $-20^{\circ} \mathrm{C}$ to 40 - C; continuous operation time: not less than 8 hours (http://viy.ua/e/products/VIY3-300_Georadar.htm).

Such technical and design characteristics provide perfect coordination of electronics, antennas, high reliability and easy application of devices.
While measurements device was on the ground and operator dragged it across buried objects. Different settings of measurement (Chernov, Loshakov 2016) and up-to-date tools for GPR-data processing (wavelet function, gain function, frequency filters) in Synchro software (by "Transient Technologies") were applied to obtain representative results.

\section{SITES OF INVESTIGATIONS}

Results of investigations from three areas are shown in this paper:

1. Experimental polygon for the study of the upper part of the geological medium (near Institute of geology of Taras Shevchenko National University, Kyiv, Ukraine). This polygon was created for testing of different geophysical methods. There are different buried objects (fig.1 a), which reflect electromagnetic signal and could be identified on radargrams (fig. 1 b). 


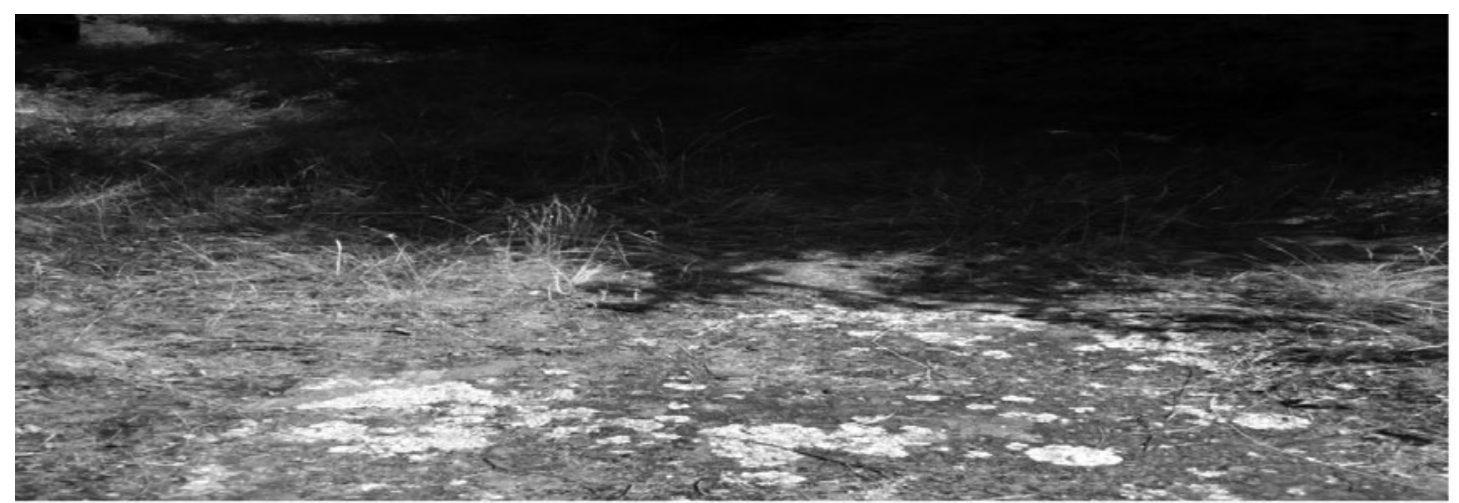

a

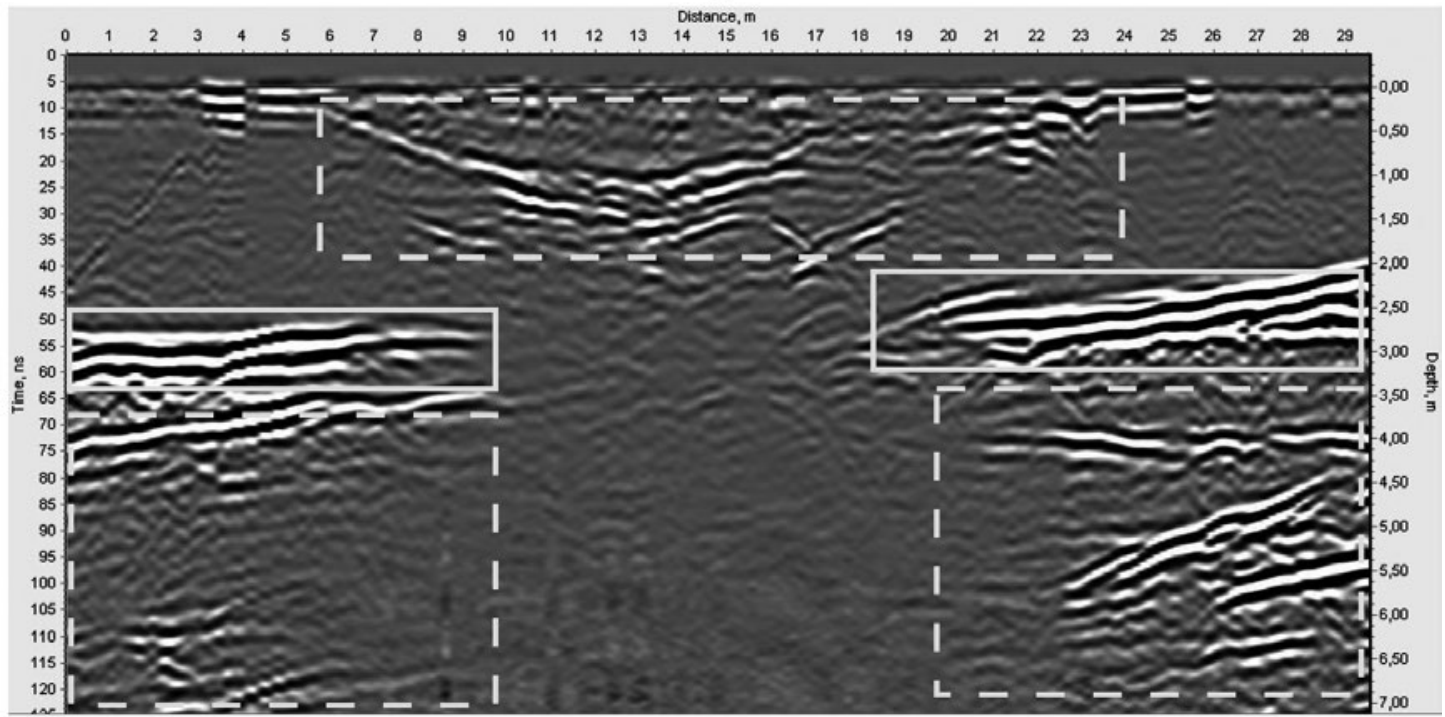

b

Fig. 3. Exposure of granites on the earth surface:

$a$ - a picture from site of investigation - border between outcrop of granites and sedimentary layer on the earth surface; $b$ - radargram obtained on this site: with dashed line anomalies in the granite structure are marked and with solid line - border between sedimentary layer and granites.

2. Granite quarry (near Kornin city, Zhytomyrs'ka oblast, Ukraine). Granite structure of this region is characterized by fracturing and one of the horizontal fractures (on the depth of $3 \mathrm{~m}$ from the surface of investigations - fig. 2 a) was filled with water.

3. Region of crystalline rocks exposure on the earth surface and their diving under the sedimentary layer (location near granite quarray, Kornin city, Zhytomyrs'ka oblast, Ukraine) (fig. 2)

4. Evaluation of the depth to the borders between layers of soil under the foundation of the building. (Volodymyrs'ka str., Kyiv, Ukraine).

\section{RESULTS}

Experimental polygon. Figure 1 shows cross-section of the polygon (fig. $1 \mathrm{a}$ ) and resulting radargram after processing (fig. 1 b). Number near each anomaly on radargram corresponds to the number for objects on the cross-section. After choosing most applicable parameters of survey (step of measurement $30 \mathrm{~mm} ; 1000$ samples per trace; length of trace (depth) $70 \mathrm{~ns}$ ) and after processing radargram depicts clear reflections from objects 1,2 , 3 , which locate close to each other, and from 5,6 , which locate above each other. Such discretization is possible thanks to length of the electromagnetic wave, which was 0.3-0.5 m on this site. However, reflections from plastic pipes $(10,11)$, metal pipes $(13,14)$ and metal plane $(8)$ are worse visible, as these objects located deeper and interference of the reflected wave from two metal objects prevent clear identification of the reflection from each of them separately. Reflections from styrofoam box (7), pipeline (12) and metal box (4) are clearly visible, because of their location and characteristics of the material, which result in strong anomaly. 


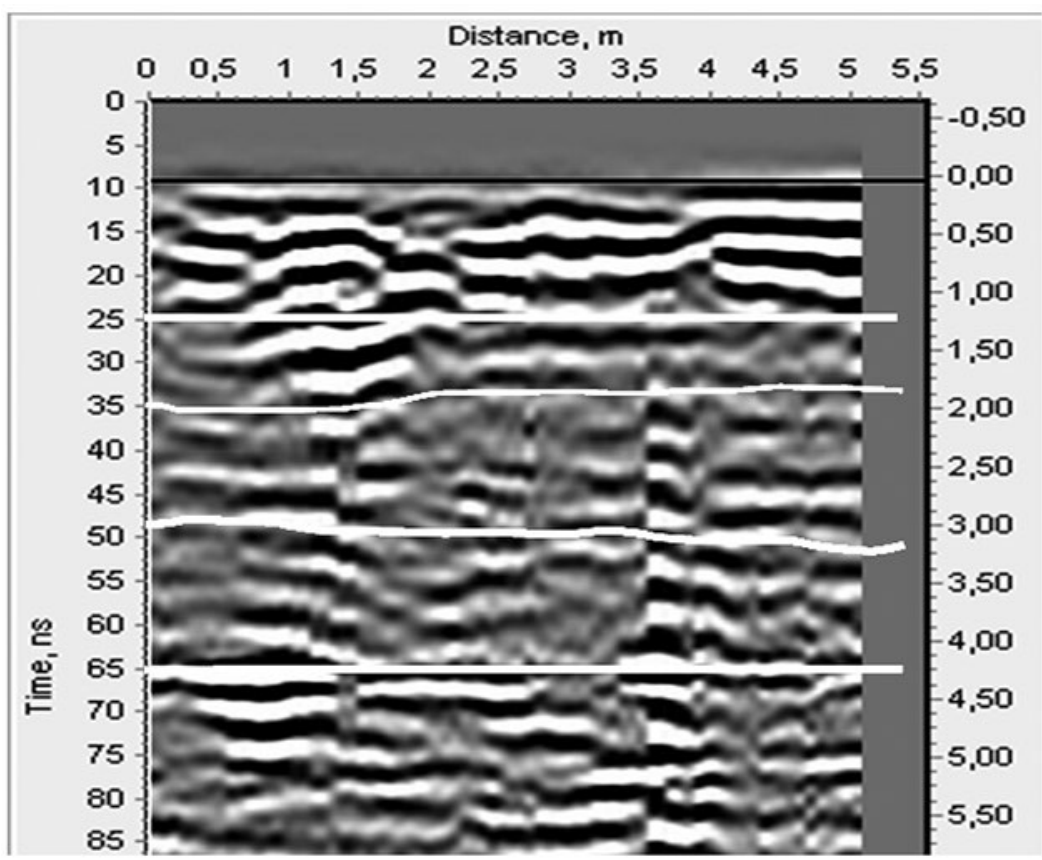

\begin{tabular}{|l|}
\hline $\begin{array}{l}\text { Composition of layer } \\
\text { (from drilling) }\end{array}$ \\
\hline $\begin{array}{l}\text { Concrete, building } \\
\text { wastes }\end{array}$ \\
\hline Backfilling \\
\hline Ductile loam \\
\hline Brittle loam \\
\hline Clayish loam \\
\hline
\end{tabular}

Fig. 4. Evaluation of the depth to the borders between layers of soil.

Granite Quarry. Difference between radargram before processing (fig.2 b) and after (fig.2 c) approve, that several steps of processing are sufficient to distinguish useful signal. As a result, higher amplitude of the signal on the radargram (fig.2 c) match to the real location of fissure with water (fig.2 a). And lower another bright linear anomaly was indicated, which considered to be provoked by fissure between granite blocks.

Region of crystalline rocks outcrops. Depth to the crystalline rocks under sedimentary layer was evaluated and heterogeneities in granite were identified, which are visible on fig. 3 b. First bright linear anomalies on the depth 2-2.5 $\mathrm{m}$ correspond to the border between sediments and granite. In the central part of radargram (from 6 to $23 \mathrm{~m}$ along vertical axis) anomalies near the earth surface correspond to outcrops of crystalline rocks and anomalies beneath this part correspond to heterogeneities in the weathered rock. Beneath 2.5 meters anomalies considered to be provoked by presence of fissures in the granite.

Evaluation of the depth to the borders between layers of soil. With the use of VIY3-300 GPR depth to the natural soil under foundation of the building was determined. The results of GPR surveying were correlated with the results of drilling on this area (fig. 4). It was possible to distinguish different layers, because on the radargram different peculiarities for reflected signal match different layers as a result of GPR surveying, this is shown on radargram on fig.4.

\section{CONCLUSIONS}

These investigations revealed that applied equipment, field technics and processing algorithms help to detect heterogeneities such as cracks filled with water, border between different rocks and soil types and artificial objects (pipes, iron boxes, wastes products from tin, plastic). Obtained results prove that VIY3-300 GPR is reliable equipment, which can be applied for solving of wide range of near surface problems. During these investigations first attempts of VIY-3 GPRs infrormativeness evaluations were done.

Aims of further research of authors are development of GPR surveying technics and algorithms for obtaining the best quality of the results in the shortest period of time; development of processing algorithms and methods of work that will help to get information about physical properties of investigated medium and to solve inverse problem of geophysics with minimal deviation thanks to combination of GPR data with other methods.

\section{ACKNOWLEDGEMENTS}

LLC "Transient Technologies" for provided equipment and for support during investigations.

Company "Leopard" (granite quarry in the suburbs of Kornin city) for the opportunity to conduct research on the territory of the quarry. 


\section{REFERENCES}

Chernov, A., Goliaka, R., 2015. Investigation of upper part of geological medium with GPR VIY3-300. Proceedings of the international scientific conference Fundamental meaning of geological education and science. Ivan Franko National University of Lviv, 7-8 October, Lviv, Ukraine, pp. 227-230. (In Ukrainian).

Chernov A., Loshakov O., 2016 Influence of GPR measure step and depth of investigation on quality of GPR profiles. Proceedings of international conference Geoinformatics 2016, 10-13 May 2016, Kyiv, Ukraine.

David J. Daniels, 2004. Ground-penetrating radar. 2nd ed. The Institution of Electrical Engineers, London, United Kingdom, pp.24-36.

Persico, R. 2014. Introduction to ground penetrating radar. John Wiley \& Sons, Inc., Hoboken, New Jersey, p. 14.

Vladov M. L., Starovoitov A.V., 2004. Introduction to GPR surveying. Moscow State University, pp.26-30. (In Russian).

LLC Transient Technologies [Web-page] - Link: http://viy. ua/e/products/VIY3-300_Georadar.htm
Чернов А. АосліАження верхньої частини геологічного середовища за Аопомогою георадара VIY3-300 / А.П. Чернов, Р.П. Голяка // Збірник матеріалів міжнародної наукової конференції “Фундаментальне значення геологічної освіти та науки" - 7-8 жовтня 2015, Аьвів, Україна - С. 227-230.

Chernov A. Influence of GPR measure step and depth of investigation on quality of GPR profiles/ Chernov A., Loshakov 0 . // proceedings of international conference Geoinformatics 2016. - 10-13 May 2016, Kyiv, Ukraine.

David J. Daniels Ground-penetrating radar. 2nd ed. / David J. Daniels // The Institution of Electrical Engineers, London, United Kingdom, - 2004. - P. 24-36.

Persico R. Introduction to ground penetrating radar. / Persico R. //John Wiley \& Sons, Inc., Hoboken, New Jersey - 2014, $14 \mathrm{p}$.

Владов М.^., Старовойтов А.В. Введение в георадиолокацию / М.А. ВлаАов, А.В. Старовойтов. - Издательство Московского университета, 2004. - С. 26-30.

ТОВ Трансієнт Текнолоджис [електронний ресурс]: [Вебсайт]. - Електронні Аані. - режим Аоступу: http://viy. ua/e/products/VIY3-300_Georadar.htm (Аата звернення 10.04.2016) - інформація з екрана.
HНI Інститут геології, Київський національний університет
ім. Тараса Шевченка

НHІ Інститут геології, Київський національний університет
ім. Тараса Шевченка Київ, Україна
Manuscript resived 30 August 2016;

revision accepted 22 November 2016

\section{А. П. Чернов, Р. П. Голяка}

\section{ОПРЕАЕАЕНИЕ НЕОАНОРОАНОСТЕЙ В ГЕОЛОГИЧЕСКОЙ СРЕАЕ С ПОМОЩЬЮ ГЕОРАААРА VIYЗ-300}

В Аанной работе преАставлены результаты исследования геологических и сАеланных человеком объектов. В статье привеАено описание методики проведения работ и технические характеристики применённого оборудования. Результаты исследований представлены в виде радарограм, которые получены в результате исследований на экспериментально-обучающем полигоне, гранитного карьера и места выхода и погружения под осадочный слой кристамлических пород. Результаты исследований показали, что при помощи георадара VIY3-300 (частота антенного блока $300 \mathrm{MHz}$ ) возможно обнаружить пластиковые и метамлические трубы, трещины, границу между породами с разной диэлектрической проницаемостью.

Ключевые слова: георадар, радарограмма, инженерная геология, гранит, приповерхностная геофизика 